\title{
Wild geophytes of ornamental interest in the native flora of southern Italy
}

\author{
Simonetta Fascetti, Giovanna Potenza, Donato Castronuovo, Vincenzo Candido \\ School of Agricultural, Forestry, Food and Environmental Sciences, University of Basilicata, \\ Potenza, Italy
}

\begin{abstract}
The growing focus on the protection and the conservation of biodiversity has attracted attention to problem of the potential invasiveness of alien species that escaped cultivation spread in various types of habitats and might replace native species. This would lead to a loss of biodiversity and have negative economic and environmental repercussions. The Mediterranean flora is particularly rich in genera and species that are characteristic of different habitats, soil and climatic conditions, and can offer exciting opportunities for innovation in the floricultural industry. In this paper we test the qualitative and quantitative data of wild geophytic species with a focus on the peninsular regions of Southern Italy. Information regarding the attributes of each species was obtained from a number of published sources, including flora and plant checklists. This selection of geophytes belonging to the spontaneous flora of Southern Italy presents a potential floricultural interest in Italy, since these plants could be used as street furniture and for gardens and turfing.
\end{abstract}

\section{Introduction}

The cultivation of ornamental plants has ancient origins. Ancient Greeks and Romans grew flowering plants, such as roses (Rosa gallica L.), lilies (Lilium candidum L.), iris (Iris spp.), violets, daffodils (Narcissus spp.) and hyacinths (Hyacinthus spp.) (Benzi and Berliocchi, 1999; Puccini, 1971; Lev, 2002) together with numerous trees and shrubs related to their traditions, myths and tales (e.g., myrtle, laurel, strawberry tree, cypress, etc.,).

However, in ancient times the main purpose for the cultivation of

Correspondence: Giovanna Potenza, School of Agricultural, Forestry, Food and Environmental Sciences, University of Basilicata, viale dell'Ateneo Lucano 10, 85100 Potenza, Italy.

E-mail: giovanna.potenza@unibas.it

Key words: biodiversity, geophytes, ornamental plants, wild species.

Received for publication: 18 February 2014.

Revision received: 19 April 2014.

Accepted for publication: 28 April 2014.

(C) Copyright S. Fascetti et al., 2014

Licensee PAGEPress, Italy

Italian Journal of Agronomy 2014; 9:595

doi:10.4081/ija.2014.595

This article is distributed under the terms of the Creative Commons Attribution Noncommercial License (by-nc 3.0) which permits any noncommercial use, distribution, and reproduction in any medium, provided the original author(s) and source are credited. many plants which are currently considered only ornamental was also intended to have medicinal plants with a high symbolic significance and an undoubted aesthetic value (Caneva, 2010).

An example is the Lilium candidum L., one of the oldest garden plants, an archaeophyte coming from Asia Minor, which was widespread in the Mediterranean area and grown mostly for the medicinal value of its bulbs and only to a lesser extent for the beauty of its flowers. In the Middle Ages, between the $9^{\text {th }}$ and the $12^{\text {th }}$ century, the Basilian and Benedictine monks followed gardening and farming traditions which were at the basis of a flourishing activity in the Mediterranean countries during the Arab-Norman period.

In Italy floriculture was already considered an economic activity in the mid-19 ${ }^{\text {th }}$ century particularly in regions such as Tuscany and Liguria (Puccini, 1971), while in Southern Italy until the end of 1800s the interest in experimental cultivations was mainly kept alive in parks, gardens and scientific botanical collections (De Rosa, 1891).

Over the last decades, the consumption of floricultural products in the western world has increased along with the improvement of living standards.

In particular, in the 1970 s the remarkable increase in the value of domestic production was a clear sign of a transition toward specialized floriculture, in particular in the Southern Italy, where the expansion of this activity led to an improvement in the quality of the products.

Currently, the strong influence of developing countries, the economic globalisation and the increase in production costs (energy and labour) have reduced the Italian nursery gardening production.

International trade tends to privilege three major production areas with significant floricultural exports to the major consumer markets: from the Netherlands and Africa to Europe, from South America to the United States and China to the other Asian countries.

In Europe, the Netherlands is the largest importer from third countries and the largest exporter both outside and inside the EU.

In addition, the Lomé Convention, signed in 1975, represented a big source of business for the major European companies, mainly Dutch, German and British, which established production sites at low costs in developing countries, while marketing products at low prices in the European countries.

Among the countries that seized this opportunity and became major exporters of flower products to the European Community, there are Kenya, Zimbabwe, Uganda and Tanzania.

In recent years the demand for nursery production of ornamental plants exotic and no-native has been implemented from that of native wild plants to be used for urban furnishings, gardens, turfing, etc.

However, in recent years, the increasing focus on the protection and the conservation of biodiversity has attracted attention to the potential problem associated with the introduction of invasive alien species that can spread in different types of habitats and replace native species with negative economic and environmental effects (Rejmanek et al., 2004). A priority in the strategies for biodiversity conservation is the identification of wild floral species to be used as ornamental plants, which can also be beneficial in terms of environmental mitigation and restoration thanks to the use of non-invasive propagation and production techniques and low cost germplasm and propagation material 
(Celesti-Grapow et al., 2010). For the conservation of target species of ornamentals, the initial focus should be on the so-called protected areas, in which unfortunately very often no inventories of species are available (Heywood, 2003). At present, attention is being paid mostly to research on native species for gardening in highly natural contexts, such as protected areas, and in geographic areas with a significant historical and cultural value and a distinctive local identity.

The great biodiversity of the Mediterranean flora is very rich in genera and species which characterise many habitats and various soil and climatic conditions and can offer interesting opportunities for innovation in the floricultural industry.

Over the last decade, a growing interest has emerged for wildspecies and wild-flowers (De Herralde et al., 1998; Sànchez-Blanco et al., 1998; Cabot and Travesa, 2000; Franco et al., 2001; MartìnezSànchez et al., 2003).

The identification of wild species with ornamental value in semiarid ecosystems, such as the Mediterranean ecosystem, can offer a real alternative to traditional production horticultural plants.

The need for cutting maintenance costs in green areas is one of the reasons for a greater interest in use of wild flora.

These plants are adapted to local environmental conditions, show many morphological and physiological strategies to overcome abiotic stress, have a good resistance to disease and a high water consumption efficiency (Morales et al., 2000; Franco et al., 2002; Clary et al., 2004; De Lucia et al., 2013).

A recent contribution to the Sicilian wild flora helped to identify some native shrubs that are characteristic of marginal environmental contexts. For species such as cysts (Cistus creticus L. s.l., C. salvifolius L.) and spurge (Euphorbia dendroides L., E. rigida M. Bieb.), there are accessions particularly suitable for pot cultivation, ornamental turfs and environmental restoration (Romano, 2008; Malorgio and Bretzel, 2008; Bretzel, 2010; Bretzel et al., 2013).

Among the most popular plants for flower production and urban design, there are geophytes, equipped with drums transformed into underground bulbs, rhizomes and tubers that are propagation structures and enable the gems to survive under conditions of environmental stress (Raunkier, 1934).

They are well diversified, have a high rate of endemic species, a good numbers of showy species and have few or no species which are already known internationally as ornamentals, which are deemed to have the greatest potential for development.

The geophytes are good commercial ornamental plants, because they have low thermal requirements, a short growing cycle and produce showy flowers. In addition, they are highly resilient to adverse seasons.

They prefer light or medium-consistency soils, as limestone with a moderate quantity of water and organic matter; they need less fertilization than other species, having reserve organs that accumulate significant amounts of nutrients.

The cultivation of ornamental geophytes includes two distinct activities: the production of bulbs and rhizomes and the production of cut flowers. In Italy, the best-developed of the two is the production of cut flowers, because the propagation material is totally imported from Holland, Israel and France. In Italy, although climatic conditions would be suitable, there are no facilities for management and marketing of propagation material.

\section{Materials and methods}

This article concerns the wild geophytes present in Italy (Conti et al., 2005), particularly in the peninsular regions of Southern Italy. The features of phenology and chorology are in line with the categories named
Flora of Italy (Pignatti, 1982; Acta Plantarum, 2011) and European Flora (Tutin et al., 1964-1993).

For topics related to the conservation status, this study is based on Regional and National Red-Lists, regional laws (Basilicata Region, 2005) and research (Fascetti and Navazio, 2007) on protected flora and the Habitats Directive 92/43/EEC (European Commission, 1992). For the study of plants recorded in the Basilicata region, which can still be seen on ancient terracotta pots and jewellery, we relied on Antica Flora Lucana (Nava et al., 2008).

\section{Results}

At present the Italian flora includes 743 geophytes out of a total of 9000 vascular plants (Conti et al., 2005). Many are geophytic species with ornamental potential.

Most of Italian geophytes have bulbs (53.4\%) and rhizomes (45.3\%) as reserve organs, which make them particularly suitable for vegetative propagation (Figure 1).

The biogeographic history of the Mediterranean flora and the geographical origin of Italian geophytes show that these are predominant species in the Mediterranean area (31\%), followed by the EuroAsian regions (13\%), circum-borealis (11\%) and endemic (11\%) (Figure 2).

The geophytes from the Mediterranean region are very interesting for the floricultural nursery and gardening activities as well as adapted to dryness and high summer temperatures. In addition, the ex situ cultivation allows us to keep a significant number of specimens from threatened populations of endemic plants.

In the peninsular regions of Southern Italy there are 458 geophytes (62\% of the total in Italy) distributed in 61 families. Eightyfive percent of these species are present in one third of households with at least 5 species per family (Figure 3 ).

As to the diversity of these species, the Orchidaceae family is the most represented $(65$ taxa $=14.2 \%)$ and includes species that so far have been little considered for nursery-gardening, because they are not easy to propagate.

However, some websites (Leneside Hardy Orchids, 2010) are recently offering propagation material of wild hardy orchids of AngloSaxon origin with many species that also present in the Southern Italian flora [e.g., Orchis mascula (L.) L. s.l., Dactylorhiza maculata (L.) Soò s.l., Dactylorhiza maculata (L.) Soò subsp. fuchsii (Druce) Hyl., Anacamptis pyramidalis (L.) Rich.], other endemic as Ophrys murgiana Cillo, Medagli \& Margherita (Medagli and Cillo, 2009) and Ophrys mateolana (Bianco et al., 1991).

Currently there is no particular interest in the exploitation of wild orchids in temperate and Mediterranean regions, although many species have suitable characteristics for floriculture, such as rapid asexual propagation, showy inflorescences of considerable size, prolonged and scalar flowering. Among the species that could be tested for cultivation, there are Orchis purpurea Huds., O. papilionacea L., Orchis mascula (L.) L. s.l., Loroglossum hircinum (L.) L.C. Rich. (Table 1).

The Iridaceae, Amarillydaceae, Hyacinthaceae and Liliaceae families, rich in species that have a consolidated role in European floriculture, are present with an interesting number of wild species (110 taxa) that are widely spread in different bioclimatic conditions and habitats. The endemic taxa are of particular biogeographic and conservation interest, some of which are exclusive of the Southern regions (e.g., Crocus imperati Ten., Colchicum bivonae Guss., Iris revoluta Colas.). Among the herbaceous grasses of Cyperaceae, Juncaceae, Poaceae and Juncaginaceae families, many rhizomatous 
species can be considered of interest for the resistance to cutting and speed of propagation. Currently some taxa, such as Cynodon dactylon L., Carex spp., Cyperus spp., Phleum spp., Festuca spp., are utilised for the turfgrass and poliphyte cultivated meadows.

Table 1 shows a selection of geophytes with potential horticultural interest that are present in the native flora of Southern Italy.

\section{Important species for biodiversity conservation}

The identification of native species with ornamental value is also interesting both to safeguard biodiversity and nature conservation and to revive the great cultural heritage related to their officinal use. Some of the best-known species, which were also recently studied

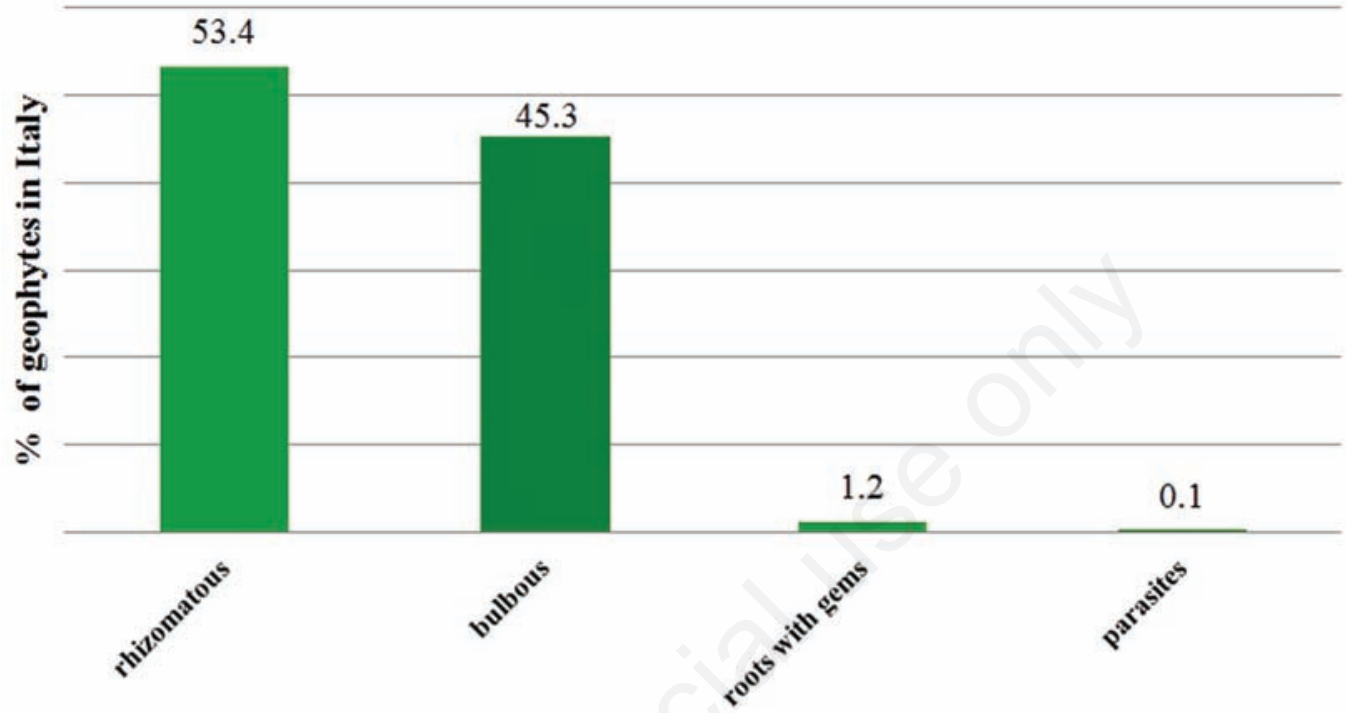

Storage organs

Figure 1. Storage organs (\%) of geophytes of the Italian flora.

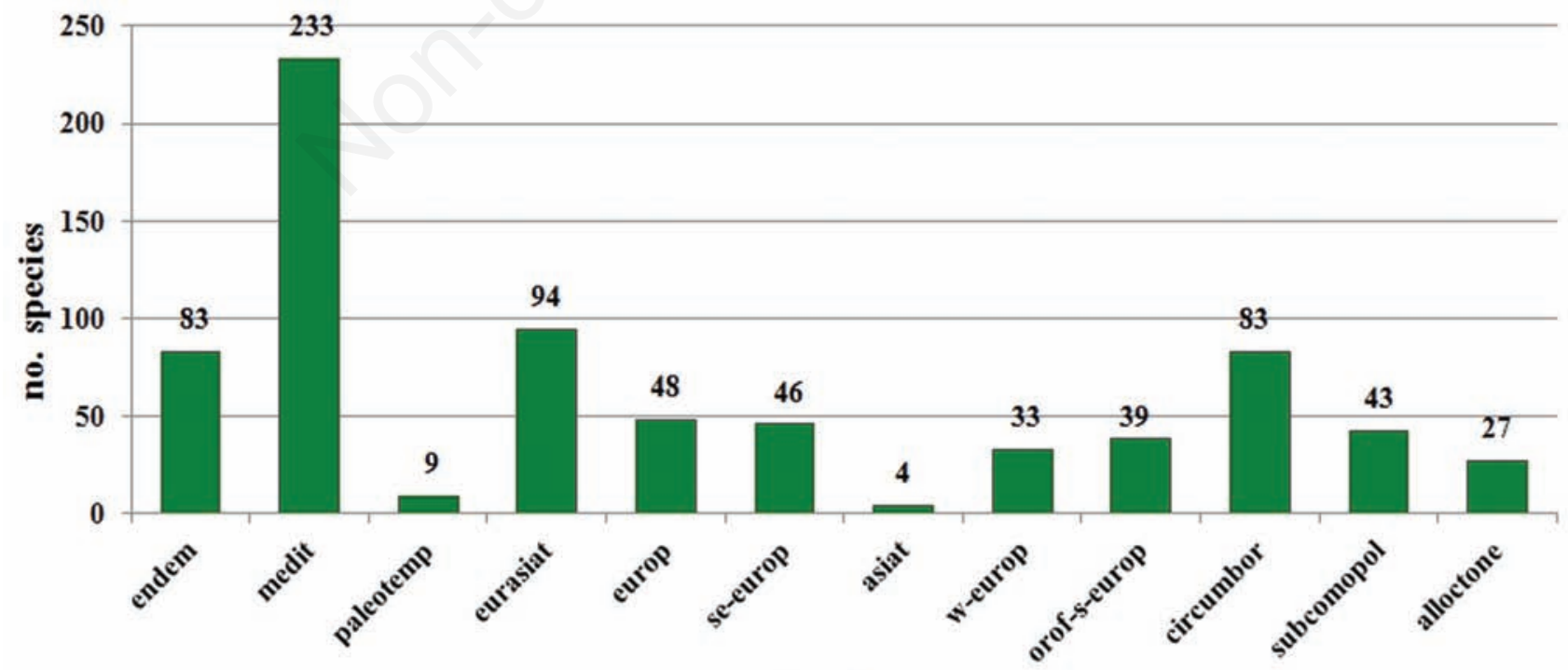

Chorology

Figure 2. Geographical origin of Italian geophytes. 
Table 1. Wild geophytes in the native flora of Southern Italy with potential interest for ornamental use.

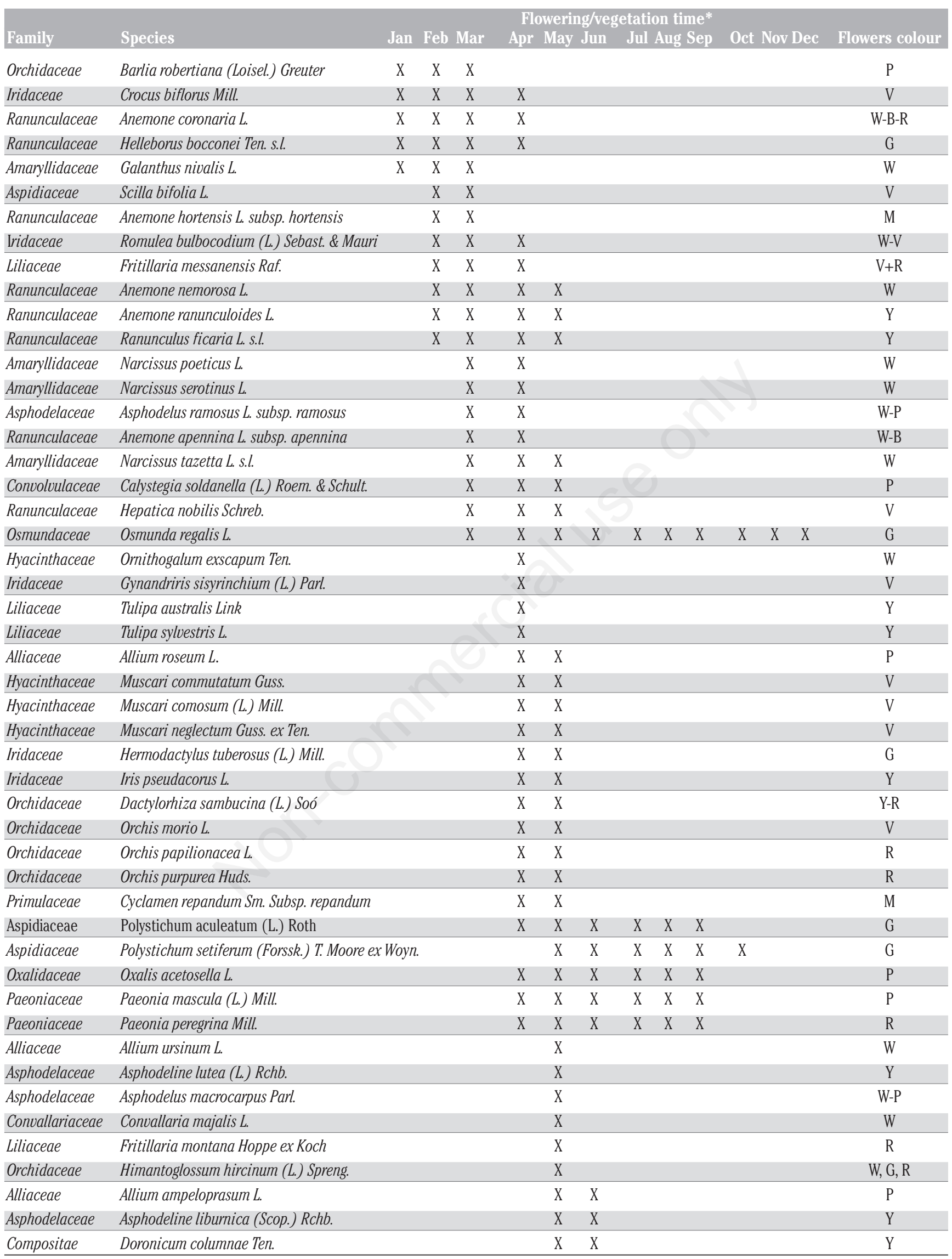


in agronomic experiments, are Muscari comosum (L.) Mill. and Bellevalia romana (L.) Sweet (cipollazzi as like lampascioni in traditional language), Glycyrrhiza glabra L. (licorice), Crocus sativus Mill. (saffron), Aparagus acutifolius L. and Ruscus aculeatus L. (wild asparagus), Allium ampeloprasum L. (wild leek), in addition to some archeophytes that have become spontaneous, as Armoracia rusticana P. Gaertn., B. Mey. \& Scherb.) (horseradish) and Lilium candidum L. s.l. (lily).

Several geophytes are typical of habitats of Community interest (Council Directive 92/43/EEC; European Commission, 1992).

The Habitats Directive is a Community legislative instrument in the field of nature conservation that establishes a common framework for the conservation of wild animal and plant species and natural habitats of Community importance; it provides for the creation of a network of special areas of conservation, called Natura 2000, to maintain and restore, at favourable conservation status, natural habi- tats and species of wild fauna and flora of Community interest (European Commission, 2007). According to the Habitats Directive, the importance of floricultural research on the propagation of geophytes of interest in the Community flora habitats is intended to make native propagation material available for the rehabilitation and restoration of damaged or degraded habitats and for environmental mitigation in infrastructure construction.

In Southern Italy there are 28 habitats that have geophytes against 110 species in total (Figure 4).

The most numerous can be found in the habitats of the mesophilous Apennine forests (32 taxa), which are marked by the early spring blooming of several species, such as anemones (Anemone apennina L.), lily of the valley (Convallaria majalis L.), snowdrop (Galanthus nivalis L.) and scilla (Scilla bifolia L.) with bulbs marketed in Italy, but of Dutch origin.

Paeonia mascula L., Paeonia peregrina L. are interesting for their

Table 1. Continued from previous page.

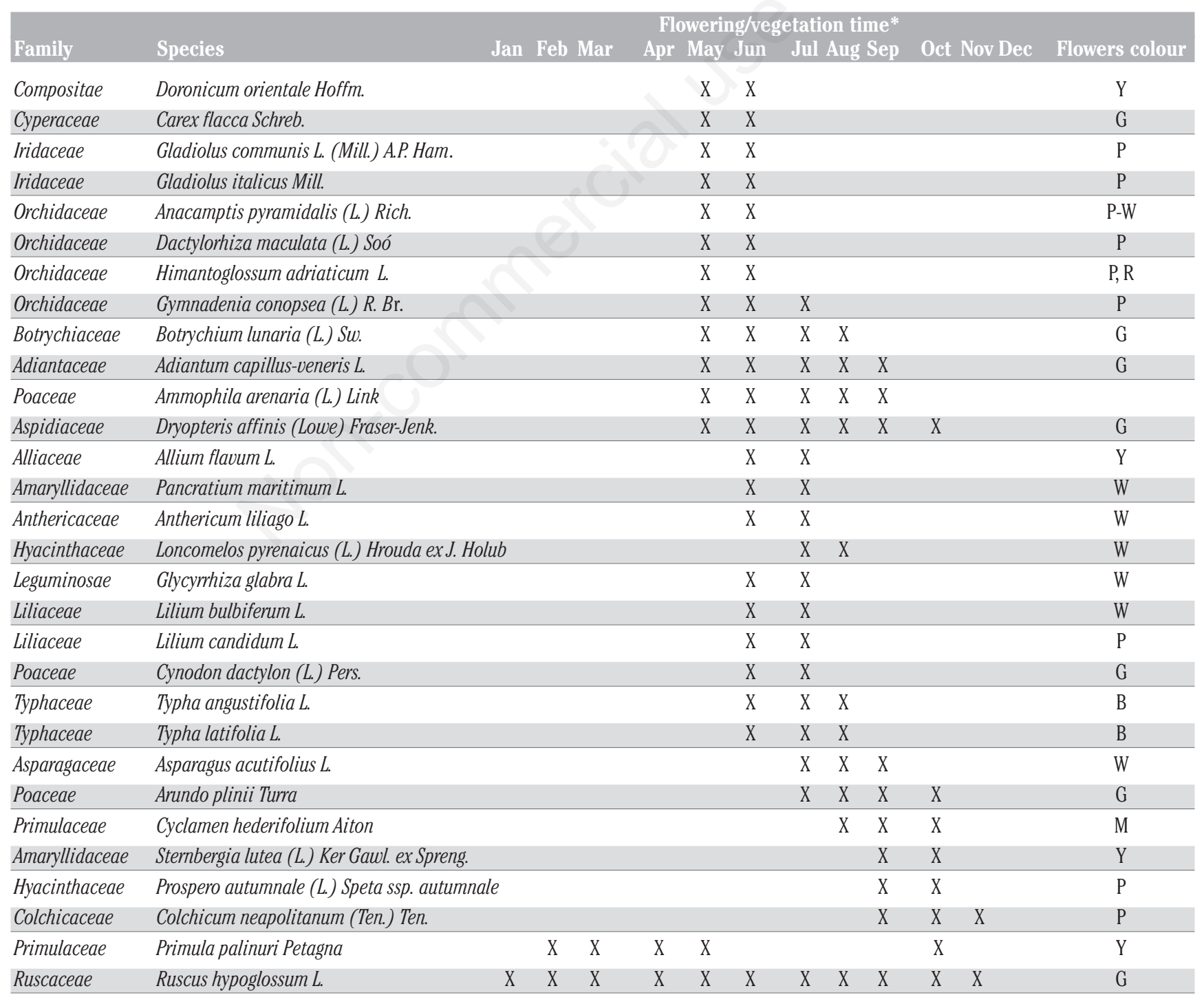

*Flowering/vegetation time is expressed in months. About flower color: G, green; P, pink; Y, yellow; W, white; B, blue; R, red; V, violet; M, mauve. 
showy blooms, while Polystichum aculeatum (L.) Roth, Polystichum setiferum (Forssk.) T. Moore ex Woyn. and Ruscus hypoglossum L. should be considered for their lush and evergreen leaves.

Even the characteristic species of Mediterranean natural and semi-natural grasslands (Habitat 6210*, 6220*, 62A0, 6420) are numerous (29 taxa). These are species with different ecological requirements, including many wild orchids and daffodils (Table 1).

Iris pseudacorus $\mathrm{L}$. and $I$. foetidissima L., among the species of the Mediterranean wetlands, are particularly decorative and suitable for planting and also to consolidate riverbanks and lakes shores.

Particularly resistant to high summer temperatures and to water stress in the Mediterranean areas are the sea lily (Pancratium maritimum L.), protected species in many regions, threatened species for the human impact.

Same interesting species are reported in Figure 5.

\section{Conclusions}

In the Mediterranean biogeographical area there is a very high number of native species that can be used as ornamental plants (Figure 4). The use of these wild geophytes can play a significant role in the conservation of biodiversity and in avoiding the loss of a great cultural heritage linked to ancient medicinal traditions. The significant importance of native plants in the Mediterranean area is also related to their high level of biodiversity, thanks to the presence, inside ecosystems, of different and heterogeneous environments that must be considered a great reserve of vegetal biodiversity. The specific utilisation of Mediterranean species as ornamental plants offers also great opportunities for decorating green spaces and restoring degraded areas, using species with high adaptability and resistance against biotic and abiotic stress.

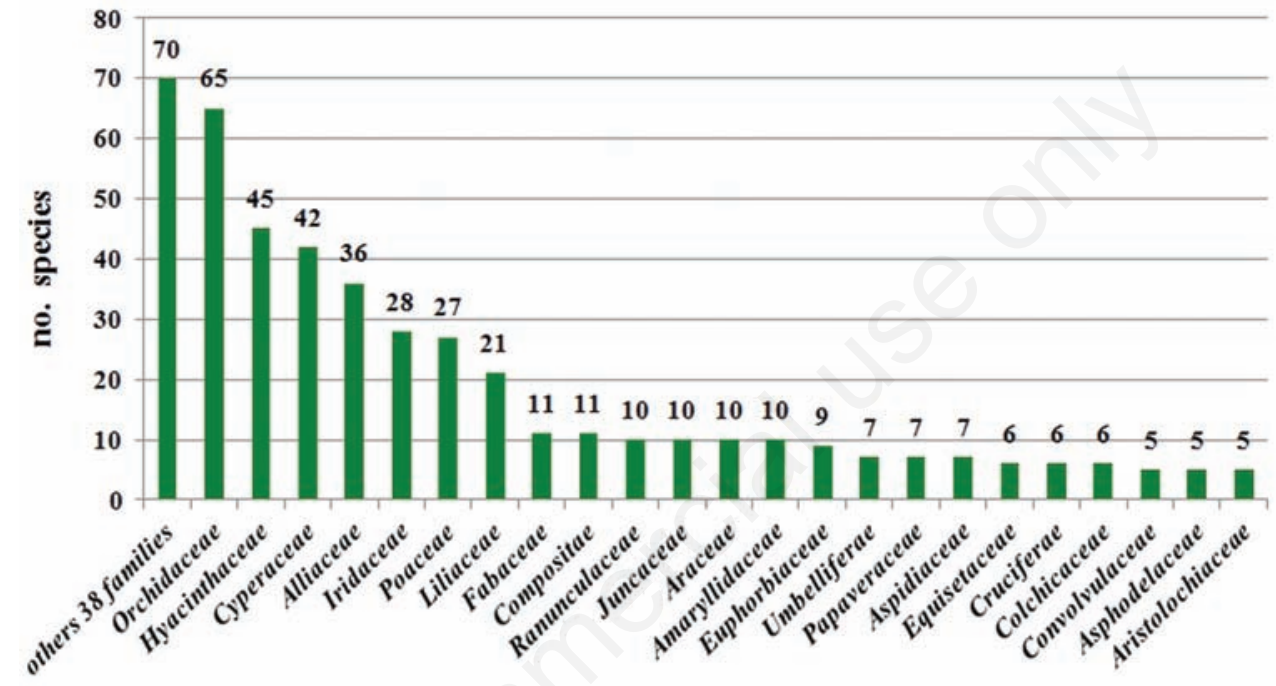

Families

Figure 3. Main families by number of geophytes in the wild flora of Southern Italy.

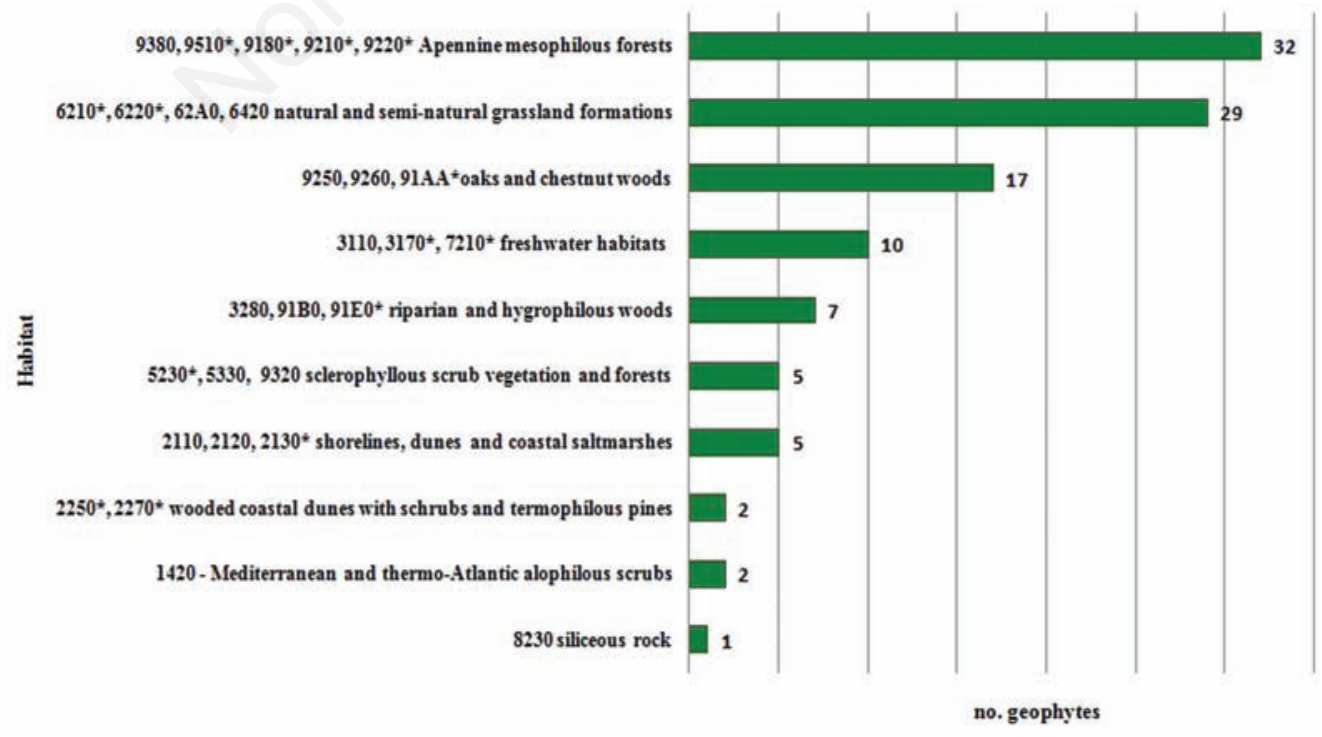

Figure 4. Number of geophytes in the UE habitat (Directive 92/43/EEC; European Commission, 1992). 

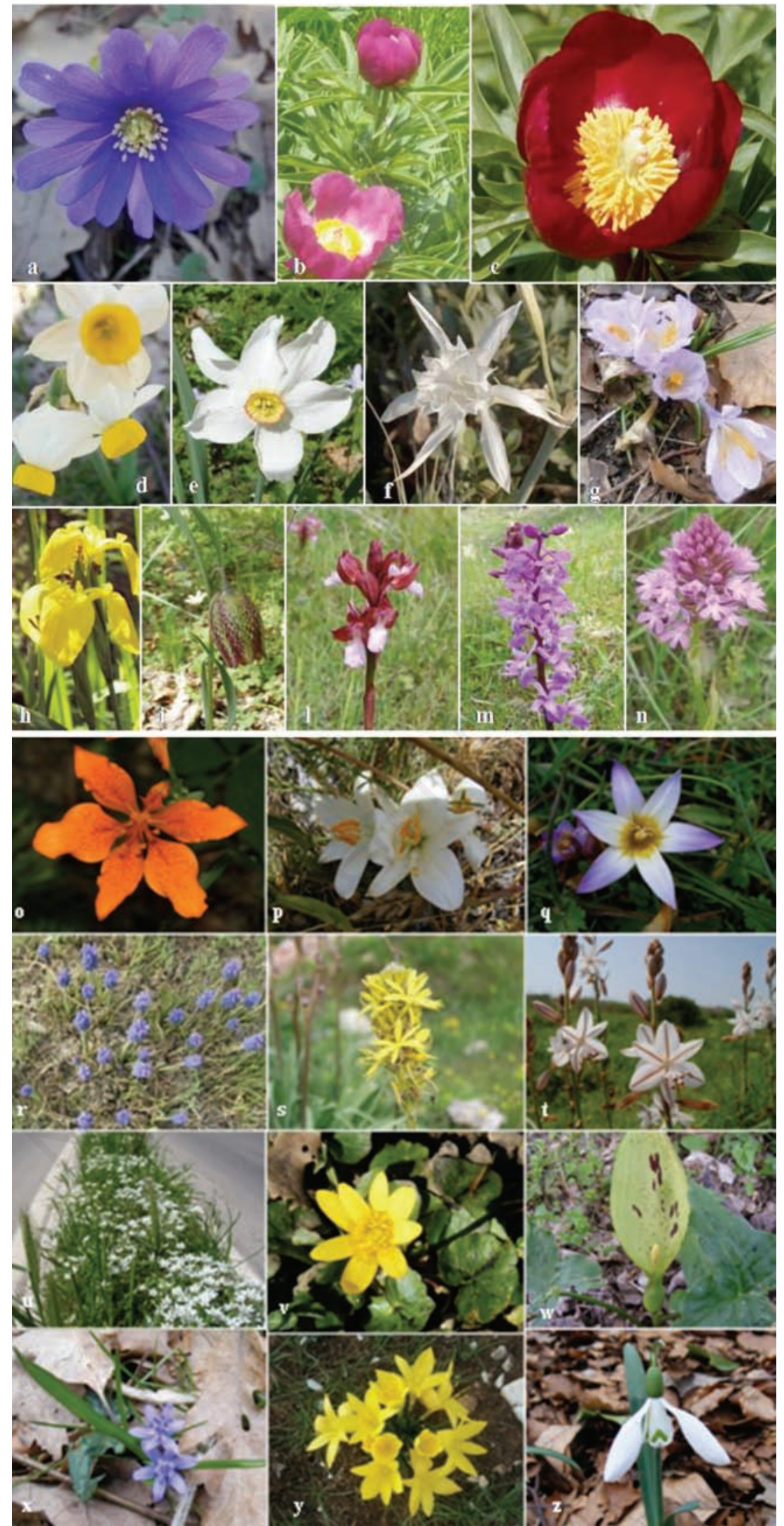

Figure 5. a) Anemone apennina; b) Peonia peregrina; c) Peonia mascula; d) Narcissus tazetta; e) Narcissus poëticus; f) Pancratium maritimum; g) Crocus sp.; h) Iris pseudacorus; i) Fritillaria tenella; 1) Ophrys papilionacea; m) Orchis mascula; n) Anacamptis pyramidalis, o) Lilium bulbiferum; p) Lilium candidum; q) Romulea bulbocodium; r) Muscari neglectum; s) Asfodelina lutea; t) Asphodelus albus; u) Ornithogalum umbellatum; v) Ranunculus ficaria; w) Arum maculatum; x) Scilla bifolia; y) Stembergia lutea; z) Galanthus nivalis. 


\section{References}

Acta Plantarum, 2011. The Italian flora. Available from: http://www.actaplantarum.org/ [In Italian].

Basilicata Region, 2005. Decreto del Presidente della Giunta Regionale 18 marzo 2005, no. 55. L.R. 28/94 - Approvazione elenco delle specie della flora lucana da proteggere. In: Boll. Uff. Regione Basilicata no. 24, 4/4/2005, pp 3003-3004. Available from: http://www.arbea.basilicata.it/index.php?option=com_docman\&tas $\mathrm{k}=$ doc_details\&gid $=1015 \&$ Itemid $=$

Benzi F, Berliocchi L, 1999. Paesaggio Mediterraneo: metamorfosi e storia dell'antichità preclassica. Federico Motta Editore, Milano, Italy.

Bianco P, Medagli P, D Emerico S, Ruggiero L, 1991. Ophrys mateolana, 231 nouvelle espèce 232 de la section Aracnitiformes dans le SudEst de 1 Italie. L Orchidophile 97:109-14.

Bretzel F, 2010. Wildflowers. In: Dipartimento Difesa della Natura (a cura del), La conservazione ex situ della biodiversità delle specie vegetali spontanee e coltivate in Italia. Stato dell'arte, criticità e azioni da compiere. ISPRA, Roma, Italy, pp 8-10.

Bretzel F, Malorgio F, Vannucchi F, Pezzarossa B, 2013. Dalla conservazione della biodiversità alla progettazione del paesaggio. Italus Hortus 20:17-31.

Cabot P, Travesa E, 2000. Empleo de planta autóctona con fines ornamentales y paisajísticos. Acta. Hortic. 31:1-5.

Caneva G, 2010. Il codice botanico di Augusto. Ara Pacis: parlare al popolo attraverso le immagini della natura. Gangemi Ed., Roma, Italy.

Celesti-Grapow L, Pretto F, Carli E, Blasi C (eds), 2010. Flora vascolare alloctona e invasiva delle regioni d'Italia. Università La Sapienza, Roma, Italy.

Clary J, Save R, Biel C, De Herralde F, 2004. Water relations in competitive interactions of Mediterranean grasses and shrubs. Ann. Appl. Biol. 144:149-55.

Conti F, Abbate G, Alessandrini A, Blasi C, 2005. An annotated checklist of the Italian vascular flora. Palombi Ed., Roma, Italy.

De Herralde F, Biel C, Savè R, Morales MA, Torrecillas A, Alarcòn JJ, Sànchez-Blanco MJ, 1998. Effect of water and salt stress on the growth, gas exchange and water relations in Argyranthemum coronopifolium plants. Plant Sci. 139:9-17.

De Lucia B, Cristiano G, Vecchietti L, Bruno L, 2013. Effect of different rates of composted 262 organic amendment on urban soil properties, growth and nutrient status of three Mediterranean 263 native hedge species. Urban Forestry Urban Green. 12:537-45.

De Rosa F, 1891. Relazione della la Esposizione Orticola Napoletana: concorso special di piante bulbose e camelie. Soc. Orticola Napoletana, Napoli, Italy.

European Commission, 1992. Council Directive 92/43/EEC of 21 May 1992 on the conservation of natural habitats and of wild fauna and flora. In: Official Journal L 206, 22/07/1992, pp 0007-0050. Available from: http://eur-lex.europa.eu/legal-content/EN/TXT/HTML/?uri= CELEX:31992L0043\&from=EN

European Commission, 2007. Interpretation manual of European Union Habitats. European Commission - DG Environment, Eur 27. Available from: http://ec.europa.eu/environment/nature/legisla- tion/habitatsdirective/docs/2007_07_im.pdf

Fascetti S, Navazio G, 2007. Specie protette, vulnerabili e rare della Flora Lucana. Ufficio Tutela della Natura, Regione Basilicata, Potenza, Italy.

Franco JA, Bañòn S, Fernandez JA, Leskovar DI, 2001. Effect of nursery regimes and establishment irrigation on root development of Lotus creticus seedling following transplanting. J. Hortic. Sci. Biotec. 76:174-9.

Franco JA, Cros V, Bañòn S, Gonzàlez A, Abrisqueta JM, 2002. Effect of nursery irrigation on postplanting root dynamics of Lotus creticus in semiarid field conditions. HortSci. 37:525-8.

Heywood V, 2003. Conservation and sustainable use of wild species as sources of new ornamentals. Acta Hort. 598:43-53.

Leneside Hardy Orchids, 2010. Leneside Hardy Orchids. Available from: http://www.lanesidehardyorchids.com/

Lev E, 2002. Recostructed materia medica of the Medieval and Ottoman Al-Sham. J. Ethnopharmacol 80:167-79.

Malorgio F, Bretzel F, 2008. Impiego di specie erbacee spontanee nella floricoltura e nella gestione del paesaggio. In: F. Malorgio, A. Pardossi, B. Pezzarossa (eds), Le piante spontanee come risorsa per il florovivaismo e la valorizzazione del paesaggio. Ed. Aracne, Roma, Italy, pp 39-50.

Martìnez-Sànchez JJ, Ferrandis P, Trabaud DL, Galindo R, Franco JA, Herranz JM, 2003. Comparative root system structure on post-fire Pinus halepensis Mill. and Cistus monspeliensis L. sampling. Plant Ecol. 168:309-20.

Medagli P, Cillo N, 2009. Ophrys murgiana Cillo, Medagli \& Margherita, specie nuova delle Murge (Puglia, Italia meridionale). GirosNotizie 41:23-5.

Morales MA, Alarcòn JJ, Torrecillas A, Sànchez-Blanco MJ, 2000. Growth and water relation of Lotus creticus creticus plants affected by salinity. Biol. Plantarum 43:413-7.

Nava ML, Osanna M, De Faveri C, 2008. Antica Flora Lucana. Ed. Osanna, Potenza, Italy.

Pignatti S, 1982. Flora d'Italia. vol. 3, Edagricole, Bologna, Italy.

Puccini G, 1971. Passato, presente e futuro della floricoltura italiana. Options Mediterraneennes 10: 40-46.

Raunkier C, 1934. The life forms of plants and Statistical Plant Geography, being the collected papers of C. Raunkier. Oxford University Press, Oxford, UK. Reprinted 1978 (ed. by Egerton) Ayer Co Pub., in the "History of Ecology Series".

Rejmánek M, Richardson DM, Pyšek P, 2004. Plant invasion and invisibility of plant communities. In: Van Der Maarel E. (eds.) Vegetation ecology. Blackwell, Malden, MA, USA, pp 332-355.

Romano D, 2008. L'utilizzazione di piante autoctone negli spazi a verde in ambiente mediterraneo. In: F: Malorgio, A. Pardossi, B. Pezzarossa (eds), Le piante spontanee come risorsa per il florovivaismo e la valorizzazione del paesaggio. Ed. Aracne, Roma, Italy, pp 11-30.

Sànchez-Blanco MJ, Morales MA, Torrecillas A, Alarcòn JJ, 1998. Diurnal and seasonal osmotic potential changes in Lotus creticus plants grown under saline stress. Plant Sci. 136:1-10.

Tutin TG, Burges NA, Chater A0, Edmondson JR, Heywood VH, Moore DM, Valentine DH, Walters SM, Webb DA, 1964-1993. Flora Europaea. Vol. 1-5. Cambridge University Press, Cambridge, UK. 